\title{
Impact Of Shareholder Activism On Corporate Governance In China: Evidence From Companies Listed On The Shenzhen Stock Exchange "A" Shares
}

\author{
Shaokai Huang, (master candidate) \\ Rui Xie, (master candidate) \\ Shanghai University, China
}

doi: 10.19044/esj.2016.v12n1p114 URL:http://dx.doi.org/10.19044/esj.2016.v12n1p114

\begin{abstract}
This paper investigates impact of shareholder activism on corporate governance in China. The separation of ownership and management of companies often to some extent causes agency problems between shareholders and company managers. In Western countries, shareholders of a company usually actively participate in the company's management and closely monitor management issues in order to enhance the company's performance. At present, China's securities market, along with institutional investors, is undergoing a rapid development. Nevertheless, problems in corporate governance among listed companies have been hindering the development of capital markets in China. Meanwhile, institutional investors have experienced significant growth. Moreover, national policies, as well as the split-share structure reform, further encourage the growth of institutional investors and their active participation in corporate governance for further promotion of the development of capital markets. Making empirical contribution, this paper tests how effective institutional investors participate in the governance of listed companies on the Shenzhen Stock Exchange (SZSE) "A" Shares after share reform in China. Results of empirical estimation indicate that China's institutional investors do participate in corporate governance, but only to some extent. Positive behaviors of Chinese shareholders have played a favorable role in improving corporate governance.
\end{abstract}

Keywords: Shareholder Activism; Institutional Investors; Corporate Governance

\section{Introduction}

Until the 1980s, institutional investors had no right to speak due to their small size in the market in Western countries, especially in America's 
capital markets. Institutional investors then often became negative shareholders in listed companies. Only when they were dissatisfied with the business decision and corporate governance would they adopt the method of "voting with feet", i.e., selling holdings to protect their own interests. At that time, the main purpose of institutional investors in the capital market is speculation. However, since the 1980s, the scale and the number of institutional investors have both grown exponentially. Institutional investors began replacing their past passive roles of speculators with long-term investors who pay more attention to the real value. Institutional investors of a company focus their attention on the company's performance for the purpose of improving and protecting the interests of minority shareholders. Positive behaviors of institutional investors have gradually become a norm in corporate governance mechanism. At the same time, institutional investors have become the backbone of the capital market.

Institutional investors change the ownership structure thoroughly because the number of the institutional investors is large. They have positive effect because they would put pressure to the board of directors and supervise managers to improve the performance of corporate governance. For this reason, they constitute into an important force to improve the traditional corporate governance, and to promote the fundamental change of corporate governance structure. The growth of institutional investors and the expansion of their influence indicate that the country's financial structure enter into a new stage of development. From the experience of developed countries, institutional investors encourage competition in the financial system, and improve the efficiency of the financial system and capital market. Market which dominated by institutional investors has the most comprehensive financial markets function. Also it is the significant way for developing market to evolve their financial market. The development of the institutional investors have large influence and promotion for emerging market countries whose capital market is dominated by banks because it could optimize the financial structure and improve the efficiency of the financial system and capital market.

China's capital markets began in the 1990s. So far it has only taken China 20 years to develop its capital market. However, the speed of its development has grown rapidly which make people impressive. At the same time, institutional investors enter into China's capital market which grows together with capital market. Institutional investors in China which have developed rapidly have begun to take shape, but they still could not have desired effect on capital market which already has a lot of problems that need to be solved. Since 2005, the stock market institutional investors such as securities investment funds, qualified foreign institutional investors (QFII), the national social security fund and fund of insurance have formed 
the diversified shape. Particularly, the reform of non-tradable shares starts in 2005 and it can effectively solve the problems about the market structure, eliminate the difference between non-tradable shares and tradable shares and realized the purpose "same share same right" which means realizing the balance of interests. At the same time, it also provides the opportunity for institutional investors to participate in corporate governance.

The main aim for Chinese institutional investors is to make use of the function of institutional investor to improve corporate governance. However, the history for the development of Chinese institutional investor is too short to reach the goal.

Research on the effects of corporate governance and performance of listed companies have reached the deep point. Actually, the related theory about institutional investor is increasingly mature. Nevertheless, domestic researchers started to find this issue late. Research on shareholder activism and its impact on corporate governance in China is scanty. At present, the domestic research on corporate governance focused on internal governance. And for external governance, researchers mainly concentrated on the market for corporate control. The problem is that studies of institutional investors governance is not enough, especially for institutional investors in corporate governance. With the rapid growth of the type and size of Chinese institutional investors, how to make institutional investors play a positive role in improving the corporate governance of listed companies in China has become a realistic urgent need of research topic.

The remaining part of this paper is organized as follows. In section two we provide definition of the relevant concepts. We summarize previous research and various definitions of these concepts. In section three, related literature is provided which contain about some previous research on corporate governance. Section four describes our data, variables and descriptive statistics of variables. In section five we develop a model that considers the effect of institutional investors on corporate governance. Section four describes the construction of our sample of shareholding of institutional investment to analyze the impact of institutional investors on corporate governance. In the next two sections we specify our empirical framework, summarize our main results, and describe how our estimates on the institutional investors. The final section concludes.

\section{Definition of Relevant Concepts}

The definition of corporate governance, shareholder activism, and institutional investors are given below. 


\section{Definition of Corporate Governance}

Corporate governance is defined as the frame of rules, relationships, systems and processes within and by which authority is practiced and controlled in corporations (ASX 2010, P3). Additionally, Corporate governance is the segmentation of the owner' power and its aim is to set up the theory to achieve responsibility between shareholders and the other department of the company (McManus and White, 2008). As a matter of fact, corporate governance affects the measures the company takes to set and realize its goals, manage the risks, and maximize the performance (ASX 2010). McManus and White (2008) points out that corporate governance could do great contribution to the company when managers direct day-to-day operations to achieve the goals and to maximize stakeholders' interest.

\section{Definition of Shareholder Activism}

Shareholder activism has not been defined in a unified, rigorous academic way. Most scholars use the concept of "shareholder activism" and the "shareholder activism" in conventional way which leads to a variety of descriptive explanation. Jamie (2005) points out that "shareholder activism" could help small and medium-sized shareholders to take all action to improve corporate governance structure, to enhance the value of the company and to ensure that all shareholders would be treated fairly. This paper argues that the "shareholder activism" refers to the behavior that institutional shareholders participating in corporate governance actively. In order to improve the condition of corporate governance and the company's performance, shareholder activism has become the important part. In addition, Hirschman (1971) support Jamie (2005) about the signification on shareholder activism. And when institutional shareholders are not satisfied with corporate governance, they would usually adopt three strategies: (1) exit, sell their shares, also known as "voting with their feet"; (2) speak, continue to hold the stock, and expressed dissatisfaction, which put pressure on the manager in many ways to reach corporate governance goal and strive to improve the return on investment; (3) loyalty, which means to continue to hold the stock. Shareholder activism is the strategy of "speak".

\section{Definition of Institutional Investors}

Academic definition of institutional investors can be also divided into two different senses. Generalized institutional investors include not only the securities investment funds, pension funds (the social security fund, etc.), insurance companies, but also several kinds of securities intermediary institutions, foundation of private donations, social charity organizations. From the narrow sense, institutional investors refer to different kinds of securities investment funds, pension funds and insurance companies. In this 
paper, we treat the institutional investors as the organization which would be entrusted by the customers who have massive funds including securities investment funds, investment companies, trust investment companies, insurance companies, savings bank, QFII. However, the QFII investment philosophy, strategy, management system and other aspects is different with the domestic institutional investors. This paper would focus on the securities investment funds, pension funds and insurance companies to represent institutional investors.

\section{Related Literature}

Previous research on institutional investors participating in corporate governance both normative studies, empirical research, generally focused on the following aspects.

\section{The Influence Factors}

Crossman and Hart (1980), Huddart (1993), Shleifer and Vishny (1997) have commended that company holding shares in the larger proportion have a stronger incentive to monitor management because their regulatory activities will earn far more than they would have to pay. Therefore, shareholders who have higher proportion of the company shares could have higher impact on corporate decisions. Carleton et al. (1998) also puts forward that improvement of shareholding requires institutional investor to act in corporate governance which is a particularly important driving factor. In the process of institutional investors participating in corporate governance, there is information asymmetry problem between them and managers and the free-rider problem resulting from small and medium-sized shareholders (Crossman and Hart, 1980; Davis, 2002). Through the analysis about institutional investors participating in corporate governance in Australia and the UK, Stapledon (1996) finds that institutional investors participating in corporate governance does give a certain benefits to the company. At the same time, the empirical results also show that institutional investors in the United States in recent years also actively involved in the corporate governance, and the activism can improve the performance of the company (Gillan and Starks, 1998). After studying a large number of UK companies, Filatotchev and Dotsenko (2013) concludes that the effectiveness of institutional investors in corporate governance depends greatly on the types of investors and their basic requirement.

\section{The Way of Institutional Investors for Participation}

Usually, the way of institutional investors participating in corporate governance includes use voting rights positively in routine meeting, voting competition authority, privately negotiation, putting forward shareholder 
proposal, supervising target companies. Several researches have focus on this problem. Grundfest (1990) argues that the way the institutional investors get involved in have been changed from negotiation and quarrel to voting for the decision, regular discussion, even including nominating managers, voting for a seat on the board through the general meeting of shareholders. Drucker (1991) argues that institutional investors who get involved corporate governance are purposed to standardize the board of directors, rather than intervene in the company. Only the board of directors represents the interests of the owners and be responsible to the shareholders could they be efficient. Paul and Bernard (2015) argue that institutional investors should approach by persuading the board or other shareholders to getting the target effect, which allows them to share the rights to perform.

\section{The Effect of Institutional Investors for Participation}

The effect of institutional investors participating in corporate governance is one of the most debated and controversial arguments among the theory researches. At present, the theoretical circle has developed two unique ideas of the corporate governance. The first one is that institutional investors participating in corporate governance has a positive effect on corporate governance. Shleifer and Vishny (1997) argue that the existence of institutional shareholders can reduce equity dispersion which caused by the "free rider" problem and can strengthen internal supervision mechanism. Chaganti (1991) uses return on assets (ROA) to present corporate performance. And his empirical research results show that the scale of institutional ownership has a significant correlation with the company's performance. Chidambaran and John (1998) argues that institutional investors such as shareholders are convenient to get inside information about the company's management from the inside company. It solves the information asymmetry problem between shareholders and the managers, which also enhance the transparency of the company and strengthen the supervision of the enterprise.

Another kind of option is that institutional shareholder has a negative effect on corporate governance. Coffee (1991) argues that institutional investors' supervision is not absolute advantage. Institutional investors mostly adopt diversification strategy because supervision is the nature of the liquidity and short-term behavior. Barnard (1992) argues that top managers have bad evaluation of institutional investors, or even hostile to its existence, which blocks the beneficial effects of the institutional investors. Karpoff (1996) even argues that those bills launched by institutional shareholders cannot lead to a suitable decision which can improve the performance of the company. There is no evidence that can prove that these bills can change its policies, improve the corporate performance, and increase the value of the 
company. Webb (2003) argues that institutional investors mostly focused on short-term performance index of the company. If institutional investors get involved in corporate governance and pressure the management pressure, it is easy to make the management have hostility and cause the various problems of company management. The goal of institutional investors and the company is different. The company managers make their effort to maximize the value of deviation. Institutional investors have no management enterprise's experience and ability comparing with the managers. Lack of professional ability would lead to worse corporate governance or give a negative impact on company. Nelson and Peterson (2004) use empirical method for target companies who have been selected in CII list. The results show that institutional shareholders have no significant effect on corporate performance although these behaviors have changed the company governance structure.

\section{Data}

This paper selects listed companies on the Shenzhen Stock Exchange (SZSE) "A" Shares after share reform in China. The data are gathered from Shenzhen Stock Exchange (SZSE) spanning from 2007 to 2014. The data set includes 468 listed companies on "A" shares. Companies on "B" shares are of small scales and therefore not considered. Among the 468 listed companies on "A" shares, financial companies lack comparable financial indicators, and companies under special treatment have ambiguous factors. Those companies are also removed. The panel data for empirical estimation consists of 402 companies across 8 years.

\section{Description of Variables}

Considering the large number of determining factors on corporate governance, the paper includes as many explanatory variables as possible in empirical estimation. Main variables are described below:

- $\quad$ Earnings Per Share (EPS): EPS is the ratio of the net profit in one year to the total number of outstanding common shares. This ratio clearly reflects the net profit created by one share. It is one of the most important measurable indicators.

- $\quad$ Return On Assets (ROA): ROA is the ratio of the net profit to the average total assets.

- $\quad$ Shareholding of Institutional Investors (INS): INS is the parameter of interest. Institutional investors generally hold a considerable number of shares of listed companies, so they will be more willing to monitor and influence company management.

- $\quad$ Shareholding of Largest Shareholder (TOP1): previous research argues that shareholding of the largest shareholder has significant influence 
on corporate governance, and this influence is not linear, but in the U-shaped format. Therefore, the paper selects this variable and tests the influence of the largest shareholders on corporate governance.

- $\quad$ Company Size (SIZE): company size has an important influence on corporate governance. In theory, the larger the company size is, the better its performance will be. However, the emergence of issues involving corporate governance, such as principal-agent problems, makes the relation between the two ambiguous. So the paper tests the effect of the company size on corporate governance. We select the natural logarithm of total assets at year end as the indicator of the company size.

- $\quad$ Financial Risk (LEV): the paper selects asset-liability ratio to measure the financial risk of listed companies. It is the ratio of the total liabilities to the total assets at year end.

- $\quad$ Corporate Growth Ability (GROWTH): corporate growth ability directly affects the performance of listed companies. Usually, the stronger the corporate growth ability is, the larger the profit space is, and the better its performance will be. A great deal of existing literature generally measures the corporate growth ability by revenue growth rate. The reason is that the index not only evaluates the change of the company's market share, but also the index predicts the growth of the company's business. Corporate growth ability is calculated as the ratio of the added value of operating revenue this year to the operating revenue last year.

- $\quad$ Total Assets Turnover (TURN): TURN is an important indicator to evaluate operating quality and efficiency of all company assets. It is the ratio of the company's net operating revenue to the average total assets. Generally, the faster the turnover is, the stronger sales ability is, and the better its performance will be.

- $\quad$ The Proportion of Circulating Shares (RTS): RTS is the ratio of circulating shares to total number of shares of listed companies. After completion of share reform in 2007, most listed companies' shares are circulating.

\section{Descriptive Statistics of Variables}

Descriptive statistics of each variable are shown in Table 2.

Table 2 Descriptive Statistics of Variables

\begin{tabular}{cccccc}
\hline Variables & Obs & Mean & SD & Min & Max \\
\hline EPS & 3216 & 0.2798953 & 0.5562205 & -4.21 & 10.51 \\
\hline ROA & 3216 & 0.05720011 & 8.529129 & -0.975715 & 1.152224 \\
\hline INS & 3216 & 0.1947788 & 19.61441 & 0 & 0.882359 \\
\hline SIZE & 3216 & 21.90575 & 1.330124 & 15.57726 & 26.95455 \\
\hline GROWTH & 3216 & 0.8029416 & 2685.531 & -0.984336 & 1497.156 \\
\hline LEV & 3216 & 0.5203162 & 20.19129 & 0.00707988 & 1.273508 \\
\hline TURN & 3216 & 0.7544149 & 0.7095799 & 0.0007 & 8.5009 \\
\hline TOP1 & 3216 & 0.3431174 & 15.71057 & 0.0362109 & 0.8940855 \\
\hline RTS & 3216 & 0.9910402 & 6.948079 & 0.2656042 & 1 \\
\hline
\end{tabular}


It can be seen from Table 2 that the biggest INS is $88.24 \%$, with the average being only $19.48 \%$. It shows that development of institutional investors in capital market is rapid, but the overall shareholding is still low. The minimum of INS is 0 , which indicates that there are still some listed companies whose stock value is low, and it is difficult to forecast their future return. The maximum of TOP1 is $89.41 \%$, the average is $34.31 \%$, and the minimum is $3.62 \%$, which shows that TOP1 of some listed companies is higher. Given that Chinese institutional investors are not mature enough, "a dominant” problem may still exist, which to a certain extent, restricts the interests of other shareholders. The average of RTS is $99.1 \%$. It indicates that after the share reform, most of the issued shares of listed companies are circulating shares, which greatly enhances the willingness of institutional investors to participate in corporate governance. Meanwhile, it is conducive to the healthy development of the capital market in China.

\section{Empirical Analysis}

Not only can institutional investors improve the equity restriction of listed companies and effectively supervise the behavior of majority shareholders who can encroach on the interests of minority shareholders, but also they can enhance corporate performance by actively participating in corporate governance. In addition, institutional investors compete for control rights, which to a certain extent, effectively check and balance the other majority shareholders. Meanwhile, this will maximize investors' return. The increase of institutional investors' shareholding makes their interests closely relate to the target company. Institutional investors are more willing to invest for the long term and actively participate in corporate governance. This will have a certain influence on corporate governance. Therefore, this paper puts forward the following hypothesises:

$\mathrm{H}_{\mathrm{A}}$ : Institutional investors can improve corporate governance, i.e., shareholding of institutional investors is positively related to corporate governance.

$\mathrm{H}_{\mathrm{B}}$ : Institutional investors cannot improve corporate governance, i.e., shareholding of institutional investors is negatively or no related to corporate governance.

\section{Econometric Model}

Corporate governance is proxied by both EPS and ROA. Shareholder activism is proxied by INS. The paper sets the EPS and ROA as dependent variables respectively, INS as the parameter of interest, then runs regressions to investigate whether shareholding of institutional investors has an influence on corporate governance after controlling the effect of relevant factors. The form of panel data model is: 


$$
\begin{aligned}
& E P S=\alpha+\beta_{1} I N S+\beta_{2} \text { TOP } 1+\beta_{3} T O P 1 S Q R+\beta_{4} S I Z E+\beta_{5} L E V \\
& +\beta_{6} T U R N+\beta_{7} G R O W T H+\beta_{8} R T S+\varepsilon, \\
& R O A=\alpha+\beta_{1} I N S+\beta_{2} T O P 1+\beta_{3} T O P 1 S Q R+\beta_{4} S I Z E+\beta_{5} L E V \\
& +\beta_{6} T U R N+\beta_{7} G R O W T H+\beta_{8} R T S+\varepsilon,
\end{aligned}
$$

where $\alpha$ is the intercept, $\beta_{i} \quad(\mathrm{i}=1,2,3,4,5,6,7,8)$ are the parameter coefficients and $\varepsilon$ is the error term.

\section{Empirical Results}

First of all, to avoid spurious regression and ensure the validity of the estimation results, this paper performs stationary test on variable EPS and ROA. Results of unit root test indicate that these two variables are both stationary. Besides, correlation analysis finds that there is no multicollinearity among independent variables. In addition, Hausman test is performed to choose between fixed effect and random effect. The result is in favor of fixed effect model. F test is conducted to choose between fixed effect and ordinary least squares (OLS). The result indicates that fixed effect model is optimal. Thus, the panel estimation model with fixed effect model is adopted.

Regression results are shown in Table 3 and Table 4. Regression 1 is the Pooled OLS, Regression 2 is the robust Pooled OLS that accounts for heteroskedasticity, Regression 3 is the incremental Pooled OLS, Regression 4 is the fixed effect, Regression 5 is the fixed effect with eliminating the heteroskedasticity, and Regression 6 is the incremental fixed effect. Due to the existence of heteroskedasticity, Regression 5 of Table 3 is optimal for

\begin{tabular}{|c|c|c|c|c|c|c|}
\hline \multirow{3}{*}{$\begin{array}{c}\text { Independent } \\
\text { Variables }\end{array}$} & \multicolumn{6}{|c|}{ Dependent Variable: EPS } \\
\hline & Regression 1 & Regression 2 & Regression 3 & Regression 4 & Regression 5 & Regression 6 \\
\hline & $\begin{array}{l}\text { Coef. } \\
\text { (S. E.) }\end{array}$ & $\begin{array}{l}\text { Coef. } \\
\text { (S. E.) }\end{array}$ & $\begin{array}{l}\text { Coef. } \\
\text { (S. E.) }\end{array}$ & $\begin{array}{l}\text { Coef. } \\
\text { (S. E.) }\end{array}$ & $\begin{array}{l}\text { Coef. } \\
\text { (S. E.) }\end{array}$ & $\begin{array}{l}\text { Coef. } \\
\text { (S. E.) }\end{array}$ \\
\hline INS & $\begin{array}{c}.0037937 * * * \\
(.0004458)\end{array}$ & $\begin{array}{c}.0037937 * * * \\
(.0004087)\end{array}$ & $\begin{array}{c}.0037937 * * * \\
(.0008028)\end{array}$ & $\begin{array}{c}.0014004 * * * \\
(.0005411)\end{array}$ & $\begin{array}{l}.0014004^{* *} \\
(.0006046)\end{array}$ & $\begin{array}{c}.0014004^{* * *} \\
(.0002583)\end{array}$ \\
\hline SIZE & $\begin{array}{c}.1710447 * * * \\
(.0071242)\end{array}$ & $\begin{array}{c}.1710447 * * * \\
(.009085)\end{array}$ & $\begin{array}{c}.1710447 * * * \\
(.0056254)\end{array}$ & $\begin{array}{c}.1692066 * * * \\
(.014267)\end{array}$ & $\begin{array}{c}.1692066 * * * \\
(.0261776)\end{array}$ & $\begin{array}{c}.1692066 * * * \\
(.0186367)\end{array}$ \\
\hline GROWTH & $\begin{array}{l}-3.44 \mathrm{e}-07 \\
(3.21 \mathrm{e}-06)\end{array}$ & $\begin{array}{l}-3.44 \mathrm{e}-07 \\
(1.02 \mathrm{e}-06)\end{array}$ & $\begin{array}{l}-3.44 \mathrm{e}-07 \\
(7.09 \mathrm{e}-07)\end{array}$ & $\begin{array}{c}8.33 \mathrm{e}-07 \\
(2.75 \mathrm{e}-06)\end{array}$ & $\begin{array}{c}8.33 \mathrm{e}-07 \\
(6.18 \mathrm{e}-07)\end{array}$ & $\begin{array}{c}8.33 e-07 \\
(4.63 e-07)\end{array}$ \\
\hline LEV & $\begin{array}{c}- \\
.0065484^{* * *} \\
(.000452)\end{array}$ & $\begin{array}{c}- \\
.0065484 * * * \\
(.0005375)\end{array}$ & $\begin{array}{c}- \\
.0065484 * * * \\
(.0003126)\end{array}$ & $\begin{array}{c}- \\
.0090382 * * * \\
(.0007217)\end{array}$ & $\begin{array}{c}- \\
.0090382 * * * \\
(.0016212)\end{array}$ & $\begin{array}{c}- \\
.0090382 * * * \\
(.0010939)\end{array}$ \\
\hline
\end{tabular}
results of EPS. All variables in Regression 6 are significant, so Regression 6 of Table 4 is optimal for results of ROA.

Table 3 Regression Results (EPS as dependent variable) 


\begin{tabular}{|c|c|c|c|c|c|c|}
\hline TURN & $\begin{array}{c}.0884606 * * * \\
(.0122586)\end{array}$ & $\begin{array}{c}.0884606 * * * \\
(.012625)\end{array}$ & $\begin{array}{c}.0884606 * * * \\
(.0107139)\end{array}$ & $\begin{array}{c}.2219468 * * * \\
(.026253)\end{array}$ & $\begin{array}{c}.2219468^{* * *} \\
(.0527162)\end{array}$ & $\begin{array}{c}.2219468^{* * *} \\
(.0262576)\end{array}$ \\
\hline TOP1 & $\begin{array}{c}.0054539 * * \\
(.0023545)\end{array}$ & $\begin{array}{c}.0054539 * * \\
(.0023702)\end{array}$ & $\begin{array}{c}.0054539 * * \\
(.0022466)\end{array}$ & $\begin{array}{c}-.0102117 * * \\
(.0045373)\end{array}$ & $\begin{array}{c}-.0102117^{*} \\
(.0057756)\end{array}$ & $\begin{array}{c}-.0102117 * * \\
(.0039383)\end{array}$ \\
\hline TOP1SQR & $\begin{array}{c}-.0000614 * * \\
(.0000289)\end{array}$ & $\begin{array}{c}-.0000614 * * \\
(.0000286)\end{array}$ & $\begin{array}{c}-.0000614^{* *} \\
(.0000257)\end{array}$ & $\begin{array}{c}.0001786 * * * \\
(.0000524)\end{array}$ & $\begin{array}{c}.0001786^{* * *} \\
(.0000678)\end{array}$ & $\begin{array}{c}.0001786^{* *} \\
(.0000539)\end{array}$ \\
\hline RTS & $\begin{array}{c}.000025 \\
(.001256)\end{array}$ & $\begin{array}{c}.000025 \\
(.0011904)\end{array}$ & $\begin{array}{c}.000025 \\
(.0011029)\end{array}$ & $\begin{array}{c}-.0007145 \\
(.0013379)\end{array}$ & $\begin{array}{c}-.0007145 \\
(.001517)\end{array}$ & $\begin{array}{c}-.0007145 \\
(.0008977)\end{array}$ \\
\hline CONSTANT & $\begin{array}{c}-3.36892 * * * \\
(.1865858)\end{array}$ & $\begin{array}{c}-3.36892 * * * \\
(.207278)\end{array}$ & $\begin{array}{c}-3.36892 * * * \\
(.2033428)\end{array}$ & $\begin{array}{c}2.984258 * * * \\
(.3419037)\end{array}$ & $\begin{array}{c}2.984258^{* * *} \\
(.548249)\end{array}$ & $\begin{array}{c}2.984258^{* * *} \\
(.3192304)\end{array}$ \\
\hline Adj.R-sq & 0.2038 & 0.2057 & 0.2057 & 0.1671 & 0.1671 & 0.1134 \\
\hline
\end{tabular}

Table 4 Regression Results (ROA as dependent variable)

\begin{tabular}{|c|c|c|c|c|c|c|}
\hline \multirow{3}{*}{$\begin{array}{l}\text { Independent } \\
\text { Variables }\end{array}$} & \multicolumn{6}{|c|}{ Dependent Variable: ROA } \\
\hline & Regression 1 & Regression 2 & Regression 2 & Regression 4 & Regression 5 & Regression 6 \\
\hline & $\begin{array}{l}\text { Coef. } \\
\text { (S. E.) }\end{array}$ & $\begin{array}{l}\text { Coef. } \\
\text { (S. E.) }\end{array}$ & $\begin{array}{l}\text { Coef. } \\
\text { (S. E.) }\end{array}$ & $\begin{array}{l}\text { Coef. } \\
\text { (S. E.) }\end{array}$ & $\begin{array}{l}\text { Coef. } \\
\text { (S. E.) }\end{array}$ & $\begin{array}{l}\text { Coef. } \\
\text { (S. E.) }\end{array}$ \\
\hline INS & $\begin{array}{c}.0288726 * * * \\
(.0071388)\end{array}$ & $\begin{array}{c}.0288726 * * * \\
(.0070849)\end{array}$ & $\begin{array}{c}.0288726 * * * \\
(.0033524)\end{array}$ & $\begin{array}{l}.0232404 * * \\
(.0093342)\end{array}$ & $\begin{array}{l}.0232404^{* *} \\
(.0113758)\end{array}$ & $\begin{array}{l}.0232404 * \\
(.0102203)\end{array}$ \\
\hline SIZE & $\begin{array}{c}1.494593 * * * \\
(.1140704)\end{array}$ & $\begin{array}{c}1.494593^{* * * *} \\
(.1601742)\end{array}$ & $\begin{array}{c}1.494593 * * * \\
(.2057385)\end{array}$ & $\begin{array}{c}1.501777 * * * \\
(.2461)\end{array}$ & $\begin{array}{c}1.501777 * * * \\
(.4509296)\end{array}$ & $\begin{array}{c}1.501777 * * * \\
(.4048337)\end{array}$ \\
\hline GROWTH & $\begin{array}{c}.0000804 \\
(.0000514)\end{array}$ & $\begin{array}{c}.0000804^{* * * *} \\
(.0000136)\end{array}$ & $\begin{array}{c}.0000804^{* * *} \\
(6.78 \mathrm{e}-06)\end{array}$ & $\begin{array}{c}.0000929 * * \\
(.0000474)\end{array}$ & $\begin{array}{c}.0000929 * * * \\
(.0000175)\end{array}$ & $\begin{array}{c}.0000929 * * * \\
(.0000175)\end{array}$ \\
\hline LEV & $\begin{array}{c}- \\
.1267154 * * * \\
(.0072369)\end{array}$ & $\begin{array}{c}- \\
.1267154 * * * \\
(.0103858)\end{array}$ & $\begin{array}{c}- \\
.1267154 * * * \\
(.0069568)\end{array}$ & $\begin{array}{c}- \\
.1704906^{* * *} \\
(.0124494)\end{array}$ & $\begin{array}{c}- \\
.1704906^{* * *} \\
(.0292926)\end{array}$ & $\begin{array}{c}- \\
.1704906 * * * \\
(.0267963)\end{array}$ \\
\hline TURN & $\begin{array}{c}1.667978 * * * \\
(.1962797)\end{array}$ & $\begin{array}{c}1.667978^{* * * *} \\
(.2045462)\end{array}$ & $\begin{array}{c}1.667978 * * * \\
(.3031404)\end{array}$ & $\begin{array}{c}4.377214 * * * \\
(.4528526)\end{array}$ & $\begin{array}{c}4.377214 * * * \\
(.9964398)\end{array}$ & $\begin{array}{c}4.377214 * * * \\
(.3555319)\end{array}$ \\
\hline TOP1 & $\begin{array}{c}.0800338^{* *} \\
(.0377001)\end{array}$ & $\begin{array}{l}.0800338^{* *} \\
(.0355248)\end{array}$ & $\begin{array}{c}.0800338^{* * *} \\
(.0137965)\end{array}$ & $\begin{array}{c}-.1651341^{* *} \\
(.0782668)\end{array}$ & $\begin{array}{l}-.1651341 \\
(.1255882)\end{array}$ & $\begin{array}{c}- \\
.1651341 * * * \\
(.0422316)\end{array}$ \\
\hline TOP1SQR & $\begin{array}{l}-.0006052 \\
(.0004633)\end{array}$ & $\begin{array}{l}-.0006052 \\
(.0004238)\end{array}$ & $\begin{array}{c}- \\
.0006052^{* * *} \\
(.00015)\end{array}$ & $\begin{array}{c}.0028412^{* * *} \\
(.0009034)\end{array}$ & $\begin{array}{c}.0028412 * * \\
(.00135)\end{array}$ & $\begin{array}{c}.0028412^{* * *} \\
(.000619)\end{array}$ \\
\hline RTS & $\begin{array}{l}-.0116494 \\
(.0201105)\end{array}$ & $\begin{array}{c}-.0116494 \\
(.0311051)\end{array}$ & $\begin{array}{c}-.0116494 \\
(.0091612)\end{array}$ & $\begin{array}{l}-.057352 * * \\
(.0230784)\end{array}$ & $\begin{array}{c}-.057352 \\
(.0402788)\end{array}$ & $\begin{array}{c}-.057352^{* * *} \\
(.0158793)\end{array}$ \\
\hline CONSTANT & $\begin{array}{c}- \\
22.98301 * * * \\
(2.98754)\end{array}$ & $\begin{array}{c}- \\
22.98301^{* * *} \\
(4.278215)\end{array}$ & $\begin{array}{c}- \\
22.98301 * * * \\
(4.237471)\end{array}$ & $\begin{array}{c}-14.76444 * * \\
(5.897682)\end{array}$ & $\begin{array}{l}-14.76444 \\
(10.50415)\end{array}$ & $\begin{array}{c}-14.76444 * * \\
(6.227204)\end{array}$ \\
\hline Adj.R-sq & 0.1318 & 0.1339 & 0.1339 & 0.1134 & 0.1134 & 0.1028 \\
\hline
\end{tabular}

Note: ${ }^{*}, * *$ and $* * *$ indicate rejection of the null hypothesis at $1 \%, 5 \%$ and $10 \%$ level of significance, respectively.

The results of two tables show similar impacts on dependent variables. As shown in Regression 5 of Table 3, INS is positively 
significant at the 5\% level. Coefficient of the variable INS is 0.0014004 , which means a 1\% increase of INS is estimated to increase EPS by $0.14004 \%$ in fixed effect model. Shareholding of institutional investors improves the degree of their willingness to participate in corporate governance. Compared to individual investors, institutional investors have superiority in size and decision to effectively supervise the management. This finally reflects in the increase of stock value. According to Regression 6 of Table 4, INS is also positively significant at the $10 \%$ level. Coefficient of the variable INS is 0.0232404 , which means a $1 \%$ increase of INS is associated with a $0.232404 \%$ increase of ROA in fixed effect model. So shareholding of institutional investors can improve the corporate governance. Therefore, SIZE and TURN present a notable positive correlation with EPS and ROA. The bigger the company size is, the faster its turnover is, and the better its performance will be.

From what has been discussed above, it is evident that shareholding of institutional investors is positively correlated with the performance of corporate governance, which complies with assumption A. So we fail to reject the assumption A.

\section{Conclusion and Policy Implications}

Compared to China, shareholding of institutional investors in the west is higher and the holding period is long. They have the motivation to participate in corporate governance, in the long run, will increase the value of listed companies. According to the previous research in America, significance of institutional investors' positive behaviors is not substitution but cooperation, i.e., institutional investors do not want to substitute for managers or weaken managers' authority, but to seek the cooperation between internal control and external control mechanism. Not only do the positive behaviors of institutional investors increase their own interests, but also improve the operating performance of listed companies. Rose and Sharfman (2015) also argues that shareholder activism can be beneficial to the enterprise. Therefore, shareholders, board of directors and regulators should pay more attention to the status of shareholder activism in business decisions.

The mechanism of Chinese institutional investors participating in corporate governance is still immature. A long time ago, due to the fact that Chinese listed companies are often in the control of large shareholders and executives, minority shareholders only focus on the volatility of stock prices in secondary market and never get a greater discourse power in corporate governance. This is the most evident before the reform of the shareholder structure. At that time, board lacks of independence and effectiveness, and management lacks a long-term 
incentive mechanism. However, with the opening of the Chinese capital market, institutional shareholders are likely to become active shareholders. Based on previous research, this paper takes into account of the actual situation. By choosing the shareholding of institutional investors as the measurement of shareholder activism and the data after the share reform of listed companies in 2007 which can eliminate the influence of non-tradable shares on shareholders of listed companies, empirical results finds that positive behaviors of Chinese shareholders have played a favorable role in improving corporate governance. The following suggestions are put forward based on empirical results.

First, to some extent, Chinese institutional investors have certain insignificant influence on corporate governance. This may be related to the lower shareholding of institutional investors and existing more serious "short-sighted" and "herd behavior" between institutional investors. This leads to the problem that shareholding of institutional investors such as securities investment funds cannot restrict to the management and offer substantial comment on corporate decisions.

Second, given growing trend of the Chinese and international securities markets, it is imperative to increase the proportion of tradable shares and develop long-term institutional investors. At present, main institutional investors in China are securities funds whose primary investors are small and medium-sized retail investors. Due to the fact that small investors' goals are short-term, this causes the investment objectives of the securities funds to be short-term as well. Therefore, securities investment funds in China, in fact, only have the nature of speculation.

Third, to promote further development of institutional investors, relevant laws and regulations should be established and improved, especially about corporate governance. In order to provide institutional conditions for institutional investors to play a leading role in listed companies, we should legislate to broaden the limit of shareholding in one listed company. For instance, strengthen the supervision of securities investment funds, increase their speculative cost, and establish an effective supervision system. Besides, government agencies should appropriately limit the liquidity of institutional investors' assets to reduce the asset turnover rate, and foster them to be the backbone of the market stability.

\section{References:}

Allen, J., Emerging Institutional Shareholder Activism in Asia[R]. Asian Corporate Governance Association, 2005.

http://www.acga-asia.org/public/files/JamieAllen_HKU_Nov05.pdf 
ASX Corporate Council, Corporate Governance Principles and Recommendations with 2010 Amendments 2nd Edition, Australian Securities Exchange.

Carleton, W. T.; Nelson, J. M. and Weisbach, M. S., The Influence of Institutions on Corporate Governance through Private Negotiations: Evidence from TIAA-CREF[J]. The Journal of Finance, 1998, 53(4): 13351362.

http://dx.doi.org/10.1111/0022-1082.00055

Chaganti, R. and Damanpour, F., Institutional Ownership, Capital Structure, and Firm Performance[J]. Strategic Management Journal, 1991, 12(7): 479491.

http://dx.doi.org/10.1002/smj.4250120702

Chidambaran, N. K. and John, K., Relationship Investing: Large Shareholder Monitoring with Managerial Cooperation[J]. New York University Working Paper, 1998.

http://ssrn.com/abstract=1297123

Coffee, J. C., Liquidity Versus Control: The Institutional Investor as Corporate Monitor[J]. Columbia Law Review, 1991, 91(6): 1277-1368.

http://www.jstor.org/stable/1123064

Davis, E. P., Institutional Investors, Corporate Governance and the Performance of the Corporate Sector[J]. Economic Systems, 2002, 26(3): 203-229.

http://dx.doi.org/10.1016/S0939-3625(02)00044-4

Drucker, P. F., Reckoning with the Pension Fund Revolution[J]. Harvard Business Review, 1991, 69(2): 106-114.

https://hbr.org/1991/03/reckoning-with-the-pension-fund-revolution

Filatotchev, I. and Dotsenko, O., Shareholder Activism in the UK: Types of Activists, Forms of Activism, and their Impact on a Target's Performance[J]. Journal of Management \& Governance, 2013, 19(1): 5-24.

http://dx.doi.org/10.1007/s10997-013-9266-5

Gillan, S. and Starks, L. T., A Survey of Shareholder Activism: Motivation and Empirical Evidence[J]. Ssrn Electronic Journal, 1998, 2(2): 10-34.

http://dx.doi.org/10.2139/ssrn.663523

Grossman, S. J and Hart, O. D., Takeover Bids, the Free-Rider Problem, and the Theory of the Corporation[J]. The Bell Journal of Economics, 1980, 11(1): 42-64.

http://www.jstor.org/stable/3003400

Grundfest, J. A., Subordination of American Capital[J]. Journal of Financial Economics, 1990, 27(1): 89-114.

http://dx.doi.org/10.1016/0304-405X(90)90022-Rq

Hirschman, A. O., Exit, Voice, and Loyalty: Responses to Decline in Firms, Organizations, and States[M]. Harvard University Press, 1970. 
http://www.hup.harvard.edu/catalog.php?isbn=9780674276604

Jara-Bertin, M.; Lopez-Iturriaga, F. J. and Lopez-de-Foronda, O., Does the Influence of Institutional Investors Depend on the Institutional Framework? An International Analysis[J]. Applied Economics, 2012, 44(3), 265-278. http://dx.doi.org/10.1080/00036846.2010.502112

Karpoff, J. M.; Malatesta, P. H. and Walkling, R. A., Corporate Governance and Shareholder Initiatives: Empirical Evidence[J]. Journal of Financial Economics, 1996, 42(3): 365-395.

http://dx.doi.org/10.1016/0304-405X(96)00883-5

McManus, J. and White, D. 2008, 'A governance perspective', Management Services, vol. 52, no. 2, pp. 14-20.

Nelson, J. and Peterson, P., Institutional Activism: Effectiveness of the CII Focus List[J]. Florida State University, 2004.

Rose, P. and Sharfman, B. S., Shareholder Activism as a Corrective Mechanism in Corporate Governance[J]. Brigham Young University Law Review, 2015, 2014(5): 1015-1052.

http://dx.doi.org/10.2139/ssrn.2324151

Shleifer, A. and Vishny, R. W., A Survey of Corporate Governance[J]. The Journal of Finance, 1997, 52(2): 737-783.

http://www.jstor.org/stable/2329497

Stapledon, G. P., Disincentives to Activism by Institutional Investors in Listed Australian Companies[J]. Oxford University Press, 1996, 18: 152. http://www.austlii.edu.au/au/journals/SydLRev/1996/8.pdf

Webb, R.; Beck, M. and McKinnon, R., Problems and Limitations of Institutional Investor Participation in Corporate Governance[J]. Corporate Governance: An International Review, 2003, 11(1): 65-73.

http://dx.doi.org/10.1111/1467-8683.00302

Zanglein, J. E., Who is Minding Your Business? Preliminary Observations on Data and Anecdotes Collected on the Role of Institutional Investors in Corporate Governance[J]. Hofstra Labor and Employment Law Journal, 1992, 10(1): 31-32.

http://scholarlycommons.law.hofstra.edu/hlelj/vol10/iss1/2 